\title{
Followership's experiences of organisational leadership: A systems psychodynamic perspective
}

\author{
Authors: \\ Henk Greyvenstein ${ }^{1}$ \\ Frans Cilliers ${ }^{1}$ \\ Affiliations: \\ ${ }^{1}$ Department of Industrial \\ and Organisational \\ Psychology, UNISA, \\ South Africa \\ Correspondence to: \\ Frans Cilliers \\ Email: \\ cillifvn@unisa.ac.za \\ Postal address: \\ PO Box 392, Unisa 0003, \\ South Africa \\ Dates: \\ Received: 31 May 2011 \\ Accepted: 24 Oct. 2011 \\ Published: 12 Mar. 2012 \\ How to cite this article: \\ Greyvenstein, H., \& Cilliers, \\ F. (2012). Followership's \\ experiences of organisational \\ leadership: A systems \\ psychodynamic perspective. \\ SA Journal of Industrial \\ Psychology/SA Tydskrif vir \\ Bedryfsielkunde, 38(2), Art. \\ \#1001, 10 pages. http:// \\ dx.doi.org/10.4102/sajip. \\ v38i2.1001
}

Orientation: Followers' experiences of leadership in their organisations were qualitatively explored and described from a systems psychodynamic perspective. The findings revealed a very negative view on how leadership treats followership, and that leadership is seen as inconsistent.

Research purpose: The purpose of the research was to describe followership's experiences of organisational leadership from a systems psychodynamic perspective.

Motivation for the study: Organisational leadership is under tremendous pressure to perform and often under attack, especially if they do not appear to be caring and supportive. The research was planned to better understand the unconscious nature of this phenomenon.

Research design, approach and method: Qualitative, descriptive research was used. Data was collected through psychodynamic Listening Posts and analysed using discourse analysis. Working hypotheses were formulated per theme and integrated into the research hypothesis.

Main findings: Six themes manifested, namely a negative leadership view; idealisation of the past and blaming the present; obsession with race and gender; constantly changing identity; unfinished business and the future; and cope and hope.

Practical/managerial implications: Leadership seem to focus more on business than followership issues which leads to followers feeling disregarded and de-authorised. As a result followers withhold authorisation from leadership which may be instrumental in leaderships' difficulties to manage change and transformation effectively. Leadership development needs to incorporate the self-authorisation of leaders as well as the invitation of authorisation by leaders.

Contribution/value-add: The data would be useful to leadership towards understanding, repairing and optimising their relationships and organisational impact through people.

\section{Introduction}

Leadership is probably one of the most published topics in business today. At the same time there is uncertainty and difference in how the concept of leadership is defined, interpreted and its characteristics described. The literature seems to focus more on leadership than on followership and the nature of the relationship between the two. This uncertainty may explain some of the anxiety in the leadership space and create opportunities for projections onto leaders as larger than life objects in organisations.

Leadership of 21st century organisations is functioning under increasing pressure and complexity (Botha, 2009; Grossman \& Valiga, 2009; Jaques, Clement \& Lessem 2003; Kets de Vries, 1990, 2001). Theoretically, leadership is constantly being deconstructed into an array of different theories, models, ideals, outcomes and desired characteristics. This is evident in the quantity of articles and books being published monthly which also results in constant changes in organisational leadership development programmes (Hanford \& Coetzee, 2003; Shokane, Stanz \& Slabbert, 2004). According to Kets de Vries (2007), this deconstruction acts as a defence against the complexity of the leadership role and its various relationships. He also mentioned that the theorising may be irrelevant because it just adds new academic and 'grand theories' to the list, which are all far removed from the reality of everyday organisational life.

In practice the complexity manifests on the three systemic levels (Kirsten, 2009), namely the macro, meso and micro systemic levels. On the macro societal and organisational levels, leadership is faced with post-modern organisational challenges, such as the new economy (Nel, 2009), globalisation, transformation, mergers, acquisitions and increased competition (Denton
(C) 2012. The Authors Licensee: AOSIS OpenJournals. This work is licensed under the Creative Commons Attribution License. 
\& Vloeberghs, 2003; Nohria \& Khurana, 2010). Coping with these demands requires thinking styles that generate creativity and utilise high levels of cognitive complexity (e.g. the legislative, judicial, hierarchical, global and liberal styles) (Murphy \& Janeke, 2009). These thinking styles are also predictors of emotional intelligence, especially in terms of optimism.

On the meso level, leadership is faced with increasingly complex technical (professional) and dynamic interpersonal (with followership) organisational systems. Coping with these demands requires constant awareness and dealing with change, conflict, chaos, paradox, diversity, power, risk, vulnerability and limited resources (including staff) (Meyer \& Boninelli, 2007). In South Africa, the specific attention to diversity management (Booysen, 2001; Coetzee, 2007) adds differentiation to the complexity as it manifests in the experienced power shifts and identity dynamics amongst different demographic groups (Havenga, 2006).

On the micro level, leadership is faced with its transforming role from managing tasks and people in a linear and mechanistic manner (Blake \& McCanse, 1995), towards taking up a dynamic and systemic leadership role - referred to as quantum leadership by Porter-O'Grady and Malloch (2007). This role implies an awareness of multiple leadership roles (such as thought, containment, symbolic and representative leadership), being able to authorise the self and followers operating within a complex matrix system and a constantly changing organisational identity, whilst managing conscious and unconscious psychological boundaries within and between conflicting subsystems (Kets de Vries, 2007). Taking up this leadership role is accompanied by high levels of survival anxiety and ultimately results in people feeling disorientated, lost, lonely, doubtful and 'not-good-enough'; they experience constant pressure to perform their tasks and to manage their relationships with followers effectively (Huffington, Armstrong, Halton, Hoyle \& Pooley, 2004; Kets de Vries, 1990, 1991, 2001; Levinson, 2006). From a positive psychology and systemic view, this role demands a lot of resilience, hardiness and sense of coherence, as well as the ability to hold the implied paradoxes of leadership (Henning, 2009).

The aforementioned literature description illustrates how leadership thinking focuses primarily on the conceptualisation of the construct, and the role and characteristics of the leader (Northouse, 2004). Followership gets relatively less attention as the object through which the organisational goal is to be reached (Meindl \& Shamir, 2007). Yun, Cox and Sims (2006) referred to this phenomenon as the forgotten follower. The purpose of the research was to describe followership's experiences of organisational leadership from a systems psychodynamic perspective.

In its extensive literature, leadership is generally defined as the activity to involve, influence, coordinate and guide people's organisational activities willingly towards attaining positive goals and outcomes for the organisation based on strategy, challenges and goals (Bass \& Avolio, 1993; Nohria \& Khurana, 2010). Leaders do this by setting and communicating direction, aligning critical constituencies, developing an executive temperament and setting and living these values (McCall, 2010).

Simplified, the aforementioned is divided between task and people management (Blake \& McCanse, 1995). This study focused on leadership's task of people management, described as how the leader includes, communicates and treats followers in a way that they feel valued, respected and by giving them options to develop themselves in their task role as well as in their personal capacities (Lowman, 2002; Nohria \& Khurana, 2010). Within the 21st century world of work, people management has become increasingly complex due to the demands of transformation, diversity, conflict, chaos, competition, paradox and limited resources (Meyer \& Boninelli, 2007). This scenario implies that leaders need to authorise themselves in matrix systems, moving between different types and styles of leadership, managing complex and diverse interpersonal relationships and dealing with a constantly changing organisational identity (Nohria \& Khurana, 2010).

South African studies focusing on coping behaviour (Jackson, 2004; Strümpfer, Eiselen, Meiring \& Phalatse, 2010; Van der Colff \& Rothmann, 2009) showed how these complex interpersonal demands act as stressors amongst leaders. These leaders present with symptoms of self-doubt, feelings of incompetence, a depletion of emotional resources, a sense of depersonalisation, a weak sense of coherence, as well as a lack of experienced organisational support. The same symptoms seem to manifest in many South African organisations where previously unknown matters surrounding culture, diversity and ethics act as challenges to traditional leadership styles (Booysen, 2001; Human, 2005). This was also found in the financial industry (Cilliers, 2011) where leaders apply their traditional financial values of governance and control in their people management role. Consequently, they are accused of not listening to, caring for or understanding their direct reports and colleagues.

Research on the experiences of followers have been reported within transformational (Avolio, Walumbwa \& Weber, 2009), neo-charismatic (Straker, 2007a, 2007b), authentic, new-genre, complexity, shared, servant (MacNeil \& McClanahan, 2005), spiritual (Fry, 2005), and cross-cultural leadership (Avolio et al., 2009). This is referred to as the dynamic embeddedness and interaction between leader and follower in terms of cognition, attributes, behaviours and contexts, also known as the leader-follower exchange. Stewardship leadership (Hernandez, 2008) focuses on relational, motivational and contextual supportive leadership behaviours to promote a sense of personal responsibility in followers for the long-term well-being of the organisation and society based on identification and intrinsic motivation, interpersonal trust and moral courage. Aesthetic leadership (Ropo \& Sauer, 2008) refers to leadership through the artistic 
metaphor of dance between leader and follower. Situational leadership refers to followership behaviour (Thompson \& Vecchio, 2009) and gives evidence of the theory's essential principle that employee outcomes are associated with prescribed leader behaviour in combination with follower developmental level. Situational and transformational leadership theories share commonalities in terms of their focus on the follower's psychology, being psychological development, and intrinsically and inspirationally motivating the follower (Daniels, 2007). Charismatic leadership (Choi, 2006) focuses on envisioning, empathy and empowerment which attend to the needs for achievement, affiliation and power amongst followers. The charismatic leader stimulates clear role perception, improved task performance, job satisfaction, collective identity, group cohesiveness, organisational citizenship and self-leadership. Groves (2005) reported the importance of leaders' social control and emotional expressivity skills and followers' openness to change. Follower self-leadership (Yun, Cox \& Sims, 2006) depends on followers' need for autonomy. Houghton and Yoho (2005) suggested that followers' development, situational urgency and task structure dictate which leadership style is appropriate (e.g. directive, transactional, transformational and/or empowering) towards followers' involvement, dependence, creativity and psychological empowerment. The aforementioned views address the relationship between leadership and followership on the conscious and mostly rational levels.

Based on Jungian psychology (Abramson, 2007) the belief is that a leadership archetype representing the unconscious preferences of human beings directs the appropriate relationship between leadership and followership. In line with Jungian thinking, this study has chosen the systems psychodynamic stance as the only leadership view to study and explore the in-depth and unconscious experiences of followership towards leadership (Cytynbuam \& Noumair, 2004).

\section{Systems psychodynamic leadership perspective}

Systems psychodynamics developed as a result of the Group Relations Training research and experiential learning events performed at the Tavistock Institute in London over the last 60 years (Brunner, Nutkevitch \& Sher, 2006; Miller, 1993). This organisational and leadership perspective is based on systemic psychoanalysis (Freud, 1921), object relations (Klein, 1988), open systems theory (Bertalanffy, 1968), social systems (Jaques, 1970; Menzies, 1993) and group relations theory (Bion, 1961). It is defined as the study of unconscious patterns of work relations (Adams \& Diamond, 1999) and their influence on leadership and authority and how role formation, conflict, identity and boundaries influence relationships and relatedness in the leadership system (Colman \& Bexton, 1975; Colman \& Geller, 1985; Cytrynbaum \& Noumair, 2004). It contains a depth psychology organisational theory (Armstrong, 2005; Gould, Stapley \& Stein, 2001) and an organisational development consultancy stance (Neumann, Kellner \& Dawson-Shepherd,
1997). The perspective is theoretically informed by five basic behavioural assumptions, namely dependency, fight or flight, pairing (Bion, 1961, 2003), me-ness (Turquet, 1974) and one-ness or we-ness (Lawrence, Bain \& Gould, 1996). It believes that the macro, meso and micro systems mirror one another and that the system as a whole strives towards equilibrium between consciousness or unconsciousness, rational or irrational behaviour, inclusion or exclusion and attachment or detachment (Czander, 1993). As a leadership development consultancy stance (Klein, 2005), the perspective offers a developmentally focused, psychoeducational process for the understanding of the deep and covert behaviour in the system. Its primary task is formulated as pushing the boundaries of awareness to better understand the unconscious meaning of systemic leadership behaviour in society and its organisations (Armstrong, 2005; Lawrence, 2000). To this end, it refers to the following specific systemic and dynamic leadership behavioural constructs (Cilliers \& Koortzen, 2005; Czander, 1993; Gould et al., 2001; Klein, 2005; Hirchhorn, 1997):

- Anxiety is defined as the fear of future, acting as the driving force (dynamo) of the relationship and relatedness between leadership and followership.

- Task refers to the basic component of work with the leader's adherence to the primary task of containing anxiety, and the diversions into off-task and anti-task behaviour where confusion and free-floating anxiety manifest.

- Role encompasses the boundary around the leadership position that differentiates it from the followership role that describes the normative, experiential and phenomenal parts of the leadership position. Of importance is how leadership takes up the role on the boundary between what is inside and what is outside in terms of the system's complexity and demands.

- Authority is the formal and official right to take up the leadership role, bestowed from above (the organisation, manager or leader), the side (colleagues), below (subordinates) and from within (self-authorisation).

- Boundaries (such as task, time or territory) act as the space around and between parts of the system, keeping it safe and contained.

- Identity describes the nature of the leader's role behaviour and the branding, climate and culture of the organisational system.

The research question was formulated as follows: given the aforementioned complexity on the macro, meso and micro leadership levels, what is followership's systems psychodynamic experience of organisational leadership? The aim of the research was to describe followership's systems psychodynamic experience around the authorisation of leadership in South Africa.

This study's contribution lies in explicating the in-depth and unconscious experiences of followership of leadership in organisations. No prior research could be found investigating this matter in a South African or international organisational context. 
The rest of the article is structured as follows: the research design is presented with reference to the research approach and strategy. This is followed by the research method consisting of the setting, roles of the researchers, sampling method, data collection, recording and analysis. Lastly, the strategies employed to ensure quality data are mentioned. Thereafter the findings are presented in six themes. In the discussion the findings were integrated in the research hypothesis, which were followed by the conclusion, recommendations, limitations and suggestions for further research.

\section{Research design \\ Research approach}

A qualitative and descriptive research approach was chosen (De Vos, Strydom, Fouché \& Delport, 2002) in order to study the 'how' and 'why' questions related to followers experiences of leadership. Hermeneutics was chosen as research paradigm (Terre Blanche, Durrheim \& Painter, 2006). During the data interpretation, the notion of self as instrument was applied (McCormick \& White, 2000; Watts, 2009) based on the epistemological assumption that empathic listening leads to increased and in-depth understanding.

\section{Research strategy}

Multiple case studies (Chamberlayne, Bornat \& Apitzsch, 2004) were used as narrative events (Breverton \& Millward, 2004). The narrative case study was useful to confine the participants' experiences in a real life context, delimited in time and place (Clarke \& Hoggett, 2009). The case studies were both intrinsic (towards understanding the phenomenon) and instrumental (towards feedback to the leadership fraternity) (Denzin \& Lincoln, 2005).

\section{Research method}

\section{Research setting}

The research was set within the leadership domain within various large organisations, investigating followers' experiences of leaders (Cytrynbaum \& Noumair, 2004). The time frame was three years stretching from January 2008 to November 2010.

\section{Entreé and establishing researcher roles}

Both researchers were involved in the planning and execution of the research. During the data gathering they took up the role of organisational consultant (Lowman, 2002) and during the analysis, the role of systems psycho-dynamically informed consultant (Neumann et al., 1997).

\section{Sampling}

Convenient (Breverton \& Millward, 2004) or opportunistic sampling (Terre Blanche et al., 2006) was used consisting of eight cases of newly identified leaders in various large South African financial organisations operating in Gauteng. Each case consisted of between five and eleven new leaders, totalling 64 participants. According to the primary South
African diversity dimensions (Cilliers \& May, 2002), the participant profile contained 52\% White participants, 33\% Black participants, 9\% Indian participants and 6\% Coloured participants, $58 \%$ female participants and $42 \%$ male participants, between the ages of 28 and 61 .

\section{Data collection methods}

A systems psychodynamic Listening Post (LP), developed by OPUS (Organisation for Promoting Understanding of Society), was used (Gould et al., 2001; Stapley, 2006a, 2006b). The design is unstructured; it operates without a pre-set outcome and explores the systems psychodynamic nature of a specific matter for two hours (Stapley \& Collie, 2005). In the first hour participants were given the task to: 'Using thinking and free association, explore your present leadership experiences in the organisation'. In the second hour participants were asked to discuss their previous exploration and to integrate these towards formulating a working hypothesis (Dartington, 2000). The researchers took up the containing role of convenor, managing the task and time boundaries. The validity of the LP is dependent on the convenor's ability to contain the event without judgement, memory or desire (Miller, 1993).

\section{Recording of data}

Hinshelwood and Skogstad's (2005) guidelines were followed. During the LPs the convenor made in vivo notes on content, followed immediately afterwards with comments on the LP on process and own subjective experiences during the event.

\section{Data analysis}

Systems psychodynamic discourse analysis was used (Smit \& Cilliers, 2006). Simple hermeneutics (Terre Blanche et al., 2006) was used to frame the discourse in terms of language and sense making (Terre Blanche et al., 2006). Double hermeneutics (Clarke \& Hoggett, 2009) was used to critically interpret the data from the system psychodynamic stance towards developing new knowledge. Themes were integrated in working hypotheses (Schafer, 2003) and eventually in the research hypothesis.

\section{Strategies employed to ensure quality data}

Ethicality (Terre Blanche et al., 2006) was assured by formally contracting the consulting and research activities with each departmental head and the participants. This included voluntary participation, informed consent and confidentiality of shared data. In terms of the research project, ethicality was ensured through the thorough design, planning, conducting and analysis of the LPs.

Trustworthiness was based on validity and credibility (Denzin \& Lincoln, 2005). The study evidenced strong and believable validity in its depth psychological description, which revealed the complexities of the concept leadership. The interpretations were peer reviewed (Brewerton \& Milward, 2004) by an independent systems psychodynamically informed psychologist who evaluated the 
dependability and saturation of the findings favourably. Credibility was assured in the competence of the researchers - both are trained in systems psychodynamic consulting and research (according to the requirements stated by Brunner et al., 2006).

\section{Reporting}

The findings were reported per manifesting theme and working hypothesis. In the discussion, the themes are integrated into the research hypothesis followed by the conclusions, recommendations, limitations and suggestions for future research.

\section{Findings}

Six themes manifested, namely, (1) a negative leadership view; (2) idealisation of the past and blaming the present; (3) obsession with race and gender; (4) constantly changing identity; (5) unfinished business and the future; and (6) cope and hope.

\section{A negative leadership view}

Participants referred to how their experiences of organisational leadership were influenced by circumstances in the world, the national and local government. They reported seeing how political power plays, corruption and social issues (e.g. violence, racism and injustice) infiltrate the organisational boundary. They reported how followers 'feel as if we live on the edge' and 'constantly expect the worst'. The aforementioned are associated with feelings of fear, anger, frustration, helplessness, uncertainty and disappointment because leadership is 'not addressing the real issues'.

Compared to politicians, participants described their organisational leadership 'at least not as corrupt'. Organisational leadership was experienced in a split manner. Leaders are experienced as successful in performing their organisational task in their professional roles (e.g. engineers, auditors and bankers) - they 'know what is going on' in their fields towards 'sustaining the organisation'. On the other hand, leaders' performance in their people management role was seen as poor. Leaders are 'pushing agendas' of change and transformation for the sake of competition with other organisations without realising their effect on their followers. Leaders are obsessed with the figures around performance but are not concerned with 'how that makes us feel' to 'constantly be hearing about more and better'. They drive change and performance from the board room without ever 'walking the floors' and 'seeing how people struggle'.

\section{Idealisation of the past and blaming the present}

When participants referred to past leaders, Mandela's name was mentioned often. He became 'our hero' - 'almost a saint'. Many organisational leaders were also idealised and described as 'strong' and 'with clear principles' - 'you always knew where you stood' and 'what was expected'. They 'were family men', 'really interested in us and our families' - 'they often sat drinking with us after work'. Present organisational leaders were described as 'distant', 'power hungry' and busy 'building their own empires'. When future organisational leaders were mentioned (which included the participants) the view was that 'they will know how to treat people with respect', 'with dignity' and awareness of what 'motivates people in today's times'. It was mentioned that past leaders stayed in their roles longer than present leaders 'who make a mistake and are then thrown out'.

\section{Obsession with race and gender}

Participants' discourses were filled with references to race and gender as if that was the cement in organisational leadership and relationships. They referred to the times when all organisations were lead by 'White, male' leaders who were seen as autocratic leaders, 'who thought the world belonged to them', 'but at least you knew what to do and what to expect'. According to participants, 'When you got into trouble you needed to please explain' and had to tread very carefully 'to get their complete forgiveness'.

Presently, leadership competence is 'high on the agenda' in all organisations. White people are generally seen as competent organisational leaders backed by their affluent backgrounds and good education. But they are 'blocked by affirmative action' which they must experience as frustrating, 'unless they start their own business', 'or emigrate'. The 'few Blacks' with the same 'good educational background as the Whites' are seen as competent leaders ('our Black CEO is a brilliant, excellent leader'). Where Black people are seen as being promoted into leadership as 'affirmative action candidates' because of their connections with inside or outside authority figures, they have to prove themselves as being good enough in an extremely critical and performance driven organisational system. This becomes 'a set up for failure' where 'we went from excellent to pathetic to nothing'. Black leaders who 'have made the transition from autocratic to networking/enabling' are seen as competent leaders.

\section{Constantly changing identity}

This discourse often included the macro South African leadership scenario. Participants framed the country's identity as positive as seen from the outside, how this has changed since 1994, and is still changing. The world has a positive view on the new multicultural democracy, modern constitution, economic growth and tourist attractions. In Africa, the country is seen as economically and socially strong. On the other hand, the internal experience is negative, filled with fear (of violence and aggression), uncertainty about who we are ('What is a rainbow nation?') and how to conduct ourselves. Citizens are trying to get to grips with the effect of the past dispensation - the country's history is re-written to include the role of the previously excluded races (i.e. Black, Coloured and Indian) and gender (e.g. adding 'her' story to 'his' story). Citizens are bombarded daily by news and experiences of loss and death as a result of uncontrollable violence, illness (such as AIDS), poverty and corruption. 
Participants reflected on how the macro identity issues are starting to reflect into organisational leadership, with extreme experience of leadership competence and incompetence. In some organisations and its divisions, leadership is experienced as highly effective in creating a climate of openness, trust and growth, and where difference is tolerated, spoken about and respected. In others, leadership is experienced as incompetent and ineffective. Incompetence is characterised by leaders managing autocratically, controlling others and checking up on them, which creates a climate filled with hostility, anger, fear, 'stuckness' and distrust. Instead of acting as leaders, they get overly involved in (micro)management. Followers experience this climate as 'unbearable and disempowering' followed by their needs and plans to leave the organisation through transfers or resignation. This happens to all followers 'irrespective of race, ethnicity, gender or age'.

\section{Unfinished business and the future}

The discourse reflected on the macro level society as being obsessed with its past, which makes it difficult to move towards forgiveness, reparation and integration. The Truth and Reconciliation Commission (TRC) was used as a metaphor. One view is that it was not effective or was not even needed based on the sentiment that the past is too threatening to work through, too insignificant to stop and think about, or that nothing has changed much. Another view is that the TRC ended too soon. During the hearings, the commission did the work ('Tutu cried for all of us') and the country looked on in amazement. There was not enough time to allow for the masses to start listening to the content and intensity in order to absorb and understand the pain. This resulted in many projections onto groups of citizens, which are still contained by them. Black participants expressed being tired of hearing how bad Black people are and that only they are responsible for crime; White people express being tired of having to defend their so-called advantaged position and to cope with their guilt about the past.

Generational issues manifested as the difficulty for the older to lead the younger and for the younger to be led by the older'. Participants expressed conflict between what leadership was, what it is and what it should be. The older leaders tend to stay within their comfort boundaries because it is the only style they know and 'it worked for so many years'. On the other hand, younger followers resent, criticise and challenge older leaders. Their desire is for leadership 'to keep up with the times', 'to move faster' and 'not be so threatened by new ideas and technology'. The new generation's entitlement to challenge leadership comes from their exposure to and knowledge about organisational and leadership development, their university studies and the Internet: 'The younger employees are taking up their leadership role to challenge the official leadership'. As a result, effective leadership and conduct and structures are emerging, similar to the predictions made in new economy thinking. On the one hand this behaviour leaves a split in the leadership system which 'is immobilising and disempowering', and on the other hand the new generation is facilitating 'a marriage between old and new thinking' in order to form a new leadership identity.
In some cases the resentment about the old style had a racial and gender content. Young Black followers expressed a longing for 'a type of TRC in organisations'. Their need is to address issues around mixed race and gender in leadership, exploring working with and reporting to someone of the opposite diversity:

'... as a Black woman, I can't trust a White male manager - I do not identify with him and what he stands for - leave alone for him to represent me and negotiate on my behalf.' (Participant $X$, financial organisation, female)

\section{Cope and hope}

With reference to the (new) political party COPE, participants mentioned that how 'followers will always cope in spite of poor leadership'. This brought hope into the stories where participants referred to how leaders come and go and 'do their own thing', maybe 'leave a good legacy' and 'maybe not'. There was a sense of 'what is new?' Leaders have left their footprints in organisations for very long - some good and some bad. It was mentioned that because we have survived similar problems in the past, we will survive these as well.

\section{Discussion}

The purpose of the research was to describe followership's experiences of organisational leadership from a systems psychodynamic perspective.

The research was important in its rich comment on organisational leadership as expressed by followership in a contained space and interpreting the views from below the surface, which are not expressed in organisations generally and easily.

The negative leadership view illustrated how the macro leadership scenario and the national experiences of citizens around anger and hurt are mirrored in the organisational experiences (Diamond \& Allcron, 2009). To cope with the anxiety, followers split their experience around corruption by projecting the bad onto the national and the relative good onto the organisational (Campbell, 2007). As soon as the focus became organisational leadership, followership again split the experience in a good and bad, projecting the good onto technical leadership and the bad onto people leadership.

\section{Working Hypothesis 1}

The experience of organisational leadership carries inherent anxiety for followership which can only be coped with by splitting and comparing it with an-other (Czander, 1993). Leadership as an object is split between a good parent taking care of technical and professional matters, and a bad parent, not taking care of people matters such as emotional and belonging needs (Klein, 1988). The object leadership is under attack because of its attachment to and preference for nonhuman objects, and detachment from its nurturing parent egostate (Erskine, 2010). 
The idealisation of the past and blaming the present, illustrated the fundamental split between past, present and future leadership (Cytrynbaum \& Noumair, 2004). Goodness and longevity were projected onto past leadership with Mandela as the hero amongst leaders. Badness was projected onto present leadership characterised by narcissism and poor relationships (Gaitanidis, 2007). Goodness was also projected onto future leadership characterised by respect, dignity and the acknowledgement of needs.

\section{Working Hypothesis 2}

In their experience of organisational leadership, followership is holding on to the past as the good and idealised object (Klein, 1988), denigrating the present and hoping for a good future. Leadership seem to be sandwiched - good bread with bad butter in between. Followers are introjecting competence in the sense of taking on a critical parent role and playing $a$ know it all game, whilst projecting their own insecurities and not knowing about what leadership is supposed to be and do, onto their present leadership (Obholzer \& Roberts, 1994).

The obsession with race and gender illustrated another split in the leadership discourse (Stapley, 1996), and adding the complexity of the diversity dimensions, race and gender (Cilliers \& May, 2002). The previously good (White) objects are excluded for not being the right fabric, and those presently included (Black) are seen as incompetent. Incompetence is projected onto White male leadership who is now punished for their past behaviour, who identified with the projection and became powerless, unless they self-authorise (Hirschhorn, 1997). To keep the balance, competence is projected onto some Black males who identified with the projection and became even more powerful in government. Followership illustrated their dependence on maintaining the competence-incompetence split in the mind (Armstrong, 2005). By splitting performance into competent and incompetent, they can, on the one hand, attach to and act out their idealised fantasies of containing good performance on behalf of the system - protect the good from being destroyed, and, on the other hand, detach from and act out their denigration of containing bad performance on behalf of the system (such as corruption, racism and non-delivery). It is as if White leadership was parked to watch Black leadership fight amongst themselves for the most democratic positions. Women were not specifically mentioned except for the many Black women in top governmental positions, which represent the exclusion in the splitting (Campbell \& Groenbaek, 2006).

\section{Working Hypothesis 3}

Race and to some extent gender is used to describe the competition for leadership. White male leadership is parked in the past, associated with failure. The leadership competition is fought amongst the Black males around criteria of connection versus transformational sophistication, whilst female Black leadership stays de-authorised and is kept in the background (Czander, 1993; Gould et al., 2004).
The references to leadership's constantly changing identity illustrated the anxiety around inconsistency and distrust (Huffington et al., 2004). The anxiety is driven by the split between the role parts of leadership as an object (Newton, Long \& Sievers, 2006). Leadership's normative role is seen as directing the task and taking care of the people (Blake \& McCanse, 1995). The phenomenal role contains projections from the world around competence and charisma whereas the existential role contains introjections of trouble, autocracy, corruption and even bullying (Rayner, Hoel \& Cooper, 2002). The difference between the parts indicate a high level of free floating anxiety (Obholzer \& Roberts, 1994) indicative of how leadership operates in the basic assumption position filled with dependence and fight or flight behaviour.

\section{Working Hypothesis 4}

Leadership is experiencing an adolescent type of identity crises (Erskine, 2010). On the outside it impresses audiences and authority figures. On the inside, the role confusion causes anxiety to followers manifesting as a lack of security and containment (Campbell \& Huffington, 2008). This crisis has a sense of 'stuckness' between growth to maturity and responsibility, or regression into messy child behaviour and de-authorising followers even further.

The unfinished business represented the flight defence into the past with its unresolved pain. The TRC is used as a container for leadership anxiety and the reverent Tutu as the idealised leader (Armstrong, 2005). Unfortunately, the TRC as container was not good enough to contain all the collective anxiety of decades of leadership memory. The wish for a continuation of the TRC in organisations in future illustrated a repetition compulsion (Huffington et al., 2004) as if a second round of reconciliation is needed to understand and master leadership. The flight defence into the future illustrated how the present leadership anxiety is projected onto the new generation, especially the young Black leaders, who become the containers of hope (Dovey, Strydom, Penderis \& Kemp, 2007; Luthans, Van Wyk \& Walumbwa, 2004).

\section{Working Hypothesis 5}

Leadership is experienced as a bad object containing unsolvable shame (Mollon, 2004), haunting organisations today. The fantasy is that it will be addressed and solved by some macro intervention. It remains difficult for individuals to become aware of their defensive behaviour followed by taking stock of their own leadership positions and to work through their issues on the micro and interpersonal levels (Henning, 2009).

Cope and hope illustrated the resilience amongst followers to reflect on leadership issues (Maddi \& Khoshaba, 2005). Yet, followership experiences alienation from leadership as if it needs to wait for leadership to realise how it functions in a disconnected manner. Followership seems willing to wait until such time, yet there is evidence of revolutionary thinking if the insights do not realise soon (Koenigsberg, 2008). 


\section{Working Hypothesis 6}

Coping with existential anxiety around leadership is based on trusting the universal, systemic and unconscious life forces towards equilibrium, linked with an inner strength to survive. The underlying belief is that the moment there is too much of one side (such as power, corruption and pain) its opposite will emerge in unexpected, surprising and interesting ways. For the present, the trust in life's fairness and balance is restored (Vansina \& Vansina-Cobbaert, 2008).

\section{Research hypothesis}

Followership experience leadership as split between a preference for the rational and mechanistic task and the avoidance of taking care of followers as people. Followership is idealising past leadership (seen as stable) and projecting incompetence onto the present power hungry Black male leadership. The object leadership is seen as bad, shameful and not having a clear identity. Furthermore, it is under attack by followership because of their experience of not being valued and cared for. Hope for a better future consists of a fantasy projected onto generalised and universal forces.

The findings showed that South African leadership is experienced by their followership as not good enough (Klein, 1988). Followership experiences leadership from its child ego state (Erskine, 2010). The rebellious child moans because nothing the parents do will be good enough. The adapted child's message is that we are not being treated in a humane or mature manner - we are hurting, not being accepted, recognised or valued. Followership experiencing itself as the child in the relationship was interpreted as the projection onto and projective identification into followership by leadership. This implies that the critical parent behaviour belongs to leadership and that the relationship is caught in a parent-child dynamic. Leadership will keep itself busy with the cognitive task of supplying mechanisms, resources and sustainability whilst not attending to the dynamic and emotional behaviour of followers. This implies that followers will not be able to authorise leadership from below which it needs to take up its role fully as strong leadership. This withholding of authorisation by followership towards leadership could explain leadership's anxiety about survival and being out of control. It could also indicate symptoms of burnout amongst leadership (Cilliers, 2005).

Although no similar research in organisation could be found, the findings generated annually by OPUS (Stapley, 2006a) comments on similar tendencies in countries around the world. Citizens are reporting not feeling contained and cared for by national leadership and authorities in governmental offices.

It was concluded that followers' view of leadership indicates the existence of immature relationships in South African organisations today. The child-parent dynamic causes high levels of anxiety amongst followers. This may be because leadership is not attending to their needs as well as because leadership is not offering a role model in the succession of leadership. The findings could explain leadership's lack of authorisation in practising servant and transformational leadership (Handford \& Coetsee, 2003).

It was recommended that leadership takes note of how it is experienced by followership and enters into continuous discourses towards understanding, repairing and optimising their relationships and organisational impact through people (Greyvenstein, 2008). Leadership development needs to incorporate the self-authorisation of leaders as well as the invitation of authorisation by leaders (April \& April, 2007; Denton \& Vloeberghs, 2003).

As a limitation of this study it could be mentioned that the view of leadership was not included. Therefore no interpretations about the other's view can be made.

It was suggested that future research should include leadership's experiences of followership. The study can be replicated in other industries as well as in government. It was also suggested that this kind of study gets done annually to measure shifts in the relationship, hopefully towards more mature and adult-adult relationships between the two parties.

\section{Acknowledgements Competing interests}

The authors declare that they have no financial or personal relationship(s) which may have inappropriately influenced them in writing this article.

\section{Authors' contributions}

H.G. (UNISA) and F.C. (UNISA) contributed equally towards the empirical and theoretical aspects. F.C. (UNISA) did the academic editing of the work.

\section{References}

Abramson, N. (2007). The leadership archetype: A Jungian analysis of similarities between modern leadership theory and the Abraham myth in the Judaic-Christian tradition. Journal of Business ethics, 72(2), 115-129.

Adams, G.B., \& Diamond, M.A. (1999). Psychodynamic perspectives on organizations: Identity, politics and change. American Behavioral Scientist, 43(2), 221-224.

April, K.A., \& April, A.R. (2007). Growing leaders in emergent markets: Leadership enhancement in the new South Africa. Journal of Management Education, 31(2), 214.

Armstrong, D. (2005). Organization in the mind: Psychoanalysis, group relations, and organizational consultancy. London: Karnac Books.

Avolio, B.J., Walumbwa, F.O., \& Weber, T.J. (2009). Leadership: Current theories, research and future directions. Annual Review of Psychology, 60, 421.

Bass, B.M., \& Avolio, B.J. (1993). Leadership theory and research: Perspectives and directions. In M.M. Chemers \& R. Ayman (Eds.), Transformational leadership: A response to critiques. San Diego, CA: Academic Press.

Bertalanffy, L.V. (1968). General systems theory: Foundations, development, applications. New York: George Braziller.

Bion, W.R. (1961). Experiences in groups. London: Tavistock Publications.

Bion, W.R. (2003). Learning from experience. London: Karnac.

Blake, R.R., \& McCanse, A.A. (1995). Leadership dilemmas - Grid solutions. Houston: Griff.

Booysen, L. (2001). The duality in South African leadership: Afrocentric or Eurocentric. South African Journal of Labour Relations, 25(3\&4), 36-64.

Botha, H. (2009). Origins, phenomena and importance of leadership. Management Today, 27(5), 29-31. 
Breverton, P., \& Millward, L. (2004). Organisational research methods. A guide for students and researchers. London: Sage.

Brunner, L.D., Nutkevitch, A., \& Sher, M. (2006). Group relations conferences. Reviewing and exploring theory, design, role-taking and application. London: Karnac.

Campbell, D., \& Gronbaek, M. (2006). Taking positions in the organisation. London: Karnac.

Campbell, D., \& Huffington, C. (2008). Organisations connected. A handbook of systemic consultation. London: Karnac.

Campbell, D. (2007). The socially constructed organisation. London: Karnac.

Chamberlayne, P., Bornat, J., \& Apitzsch, U. (2004). Biographical methods and professional practice. An international perspective. Bristol: Policy Press.

Choi, J. (2006). A motivational theory of charismatic leadership: Envisioning, empathy, and empowerment. Journal of Leadership and Organizational Studies, 13(1) 24-43.

Cilliers, F. (2011). Positive psychology leadership coaching experiences in a financial organisation. SA Journal of Industrial Psychology/SA Tydskrif vir Bedryfsielkunde, 37(1), Art. \#933, 14 pages. http://dx.doi.org/10.4102/sajip.v37i1.933

Cilliers, F. (2005). Executive coaching experiences. A systems psychodynamic perspective. South African Journal of Industrial Psychology, 31(3), 23-30.

Cilliers, F., \& Koortzen, P. (2005). Conflict in groups. The CIBART model. HR Future, October, 52-53.

Cilliers, F., \& May, M. (2002). South African diversity dynamics. Reporting on the 2000 Robben Island Diversity Experience. A Group Relations event. South African Journal of Labour Relations, 26(3), 42-68.

Clarke, S., \& Hoggett, P. (2009). Researching beneath the surface. Psycho-social research methods in practice. London: Karnac.

Coetzee, O. (2007). Exploring interpersonal and inter-group diversity dynamics in South African organisations by means of a theoretical model. Unpublished DCom thesis, University of South Africa, Pretoria.

Colman, A.D., \& Bexton, W.H. (1975). Group relations reader 1. Washington: The A.K. Rice Institute.

Colman, A.D., \& Geller, M. H. 1985. Group relations reader 2. Washington: The A.K. Rice Institute.

Cytrynbaum, S., \& Noumair, A. (2004). Group relations reader: 3. Washington: The A.K. Rice Institute.

Czander, W.M. (1993). The psychodynamics of work and organizations - Theory and application. New York: Guilford Press.

Daniels, D.M. (2007). Follower readiness - Situational leadership theory and transformational leadership theory: An interpretation of the commonalities. Allied Academics International Conference. Academy of Strategic Management Proceedings, 6(1), 11.

Dartington, T. (2000). The pre-occupation of the citizen - Reflections from the OPUS Listening Posts. Organisational and Social Dynamics, 1, 94-112.

De Vos, A.S., Strydom, H, Fouché, C.B., \& Delport, C.S.L. (2002). Research at grass roots. For the social sciences and human service professions. Pretoria: Van Schaik.

Denton, M., \& Vloeberghs, D. 2003. Leadership challenges for organisations in the new South Africa. Leadership \& Organization Development Journal, 24(1/2), 84. http://dx.doi.org/10.1108/01437730310463279

Denzin, N.K., \& Lincoln, Y.S. (2005). The Sage handbook of qualitative research. London: Sage.

Diamond, M.A., \& Allcorn, S. (2009). Private selves in public organizations. The psychodynamics of organisational diagnosis and change. New York: Palgrave.

Dovey, K., Strydom, A., Penderis, B., \& Kemp, P. (2007). Leading change in the South African district health service. The International Journal of Public Sector Management, 20(3), 192. http://dx.doi.org/10.1108/09513550710740607

Erskine, R. (2010). Life scripts: A transactional analysis of unconscious behaviour. London: Karnac.

Freud, F. (1921). Group psychology and the analysis of the ego. Complete works of Sigmund Freud. London: Hogarth.

Fry, L.W. (2005). Toward a theory of spiritual leadership. The Leadership Quarterly, 16(5), 619-722. http://dx.doi.org/10.1016/j.leaqua.2005.07.001

Gaitanidis, A. (2007). Narcissism. A critical reader. London: Karnac.

Gould, L.J., Stapley, L.F., \& Stein, M. (2001). The systems psychodynamics of organisations. London: Karnac.

Gould, L.J., Stapley, L.F., \& Stein, M. (2004). Experiential learning in organisations. Applications of the Tavistock group relations approach. London: Karnac.

Greyvenstein, H. (2008). Understanding current South African leadership dynamics from the system psychodynamic perspective. Unpublished MBL dissertation, University of South Africa, Pretoria.

Grossman, S.C., \& Valiga, T.M. (2009). The new leadership challenge. Creating the future of nursing. Philadelphia: Davis.

Groves, K.S. (2005). Linking leader skills, follower attitudes and contextual variables via an Integrated Model of Charismatic Leadership. Journal of Management, 31(2) 255-277. http://dx.doi.org/10.1177/0149206304271765

Handford, J.S., \& Coetsee, L.D. (2003). Essential transformational leadership skills to mobilize people: Combating Africa pessimism, the South African leadership challenge. Organization Development Journal, 21(1), 20

Havenga, R. (2006). South Africa needs a leadership team. Management Today, $22(9), 5$
Henning, S. (2009). Towards a system psychodynamic model of psychological wellness. Unpublished DPhil thesis, University of South Africa, Pretoria.

Hernandez, M. (2008). Promoting stewardship behaviors in organizations: A leadership model. Journal of Business Ethics, 80(1), 121-128. http://dx.doi.org/10.1007/ s10551-007-9440-2

Hinshelwood, R.D., \& Skogstad, W. (2005). Observing organisations. Anxiety, defence and culture in health care. London: Routledge.

Hirschhorn, L. (1997). Reworking authority. Leading and following in the post-modern organisation. London: MIT.

Houghton, J.D., \& Yoho, S.K. (2005). Toward a contingency model of leadership and psychological empowerment: When should self-leadership be encouraged? Journal of Leadership \& Organizational Studies, 11(4), 65-83. http://dx.doi. org/10.1177/107179190501100406

Huffington, C., Armstrong, A., Halton, W., Hoyle, L., \& Pooley, J. (2004). Working below the surface. The emotional life of contemporary organisations. London: Karnac.

Human, L. (2005). Diversity management for business success. Pretoria: Van Schaik.

Jackson, L.T.B. (2004). Burnout and engagement of teachers in the North West Province. Unpublished doctoral thesis, North-West University, Potchefstroom.

Jaques, E. (1970). Work, creativity and social justice. New York: International Universities Press.

Jaques, E., Clement, S.D., \& Lessem, R. (2003). Executive leadership: A practical guide to managing complexity. Arlington: Cason Hall.

Kets de Vries, M.F.R. (1990). Leaders on the couch. Journal of Applied Behavioral Science. Special Issue: Character and leadership, 26(4), 423-431.

Kets De Vries, M.F.R. (1991). Organisations on the coach. Clinical perspectives on organisational behaviour and change. San Francisco: Jossey-Bass.

Kets De Vries, M.F.R. (2001). The leadership mystique. London: Prentice Hall.

Kets De Vries, M.F.R. (2007). Coach and couch. London: Palgrave.

Kirsten, K. (2009). Making the leadership leap: Successful leadership. Management Today, 27(5), 32-34

Klein, L. (2005). Working across the gap. The practice of social science in organisations. London: Karnac.

Klein, M. (1988). Envy and gratitude and other works 1946-1963. London: Hogarth. Koenigsberg, R.A. (2008). The nation. A study in ideology and fantasy. Charlotte: IAP.

Lawrence, W.G., Bain, A., \& Gould, L. (1996). The fifth basic assumption. London: Tavistock.

Lawrence, W.G. (2000). Tongued with fire. Groups in experience. London: Karnac. Levinson, H. (2006). The Psychology of leadership. Boston: Harvard Business School.

Lowman, R.L. (2002). The handbook of organizational consulting Psychology. San Francisco: Jossey-Bass.

Luthans, F., Van Wyk, R., \& Walumbwa, F.O. 2004. Recognition and development of hope for South African organizational leaders. Leadership \& Organization Development Journal, 25(5/6), 512. http://dx.doi. org/10.1108/01437730410556752

MacNeil, A., \& McClanahan, A. (2005). Shared Leadership. Retrieved March 08, 2007 from http://cnx.org/content/m12923/1.2/

Maddi, S.R. \& Khoshaba, D.M. (2005). Resilience at work. How to succeed no matter what life throws at you. New York: AMACOM.

McCall, M.W. (2010). Recasting leadership development. Industrial \& Organisational Psychology, 3, 3-19.

McCormick, D.W., \& White, J. (2000). Using one's self as instrument for organisationa diagnosis. Organisational Development Journal, 18(3), 49-62.

Meindl, J.R., \& Shamir, B. (2007). Follower-centred perspectives on leadership: A tribute to the memory of James R. Meindl. Greenwich: IAP.

Menzies, I.E.P. (1993). The functioning of social systems as a defence against anxiety. London: Tavistock Institute.

Meyer, T., \& Boninelli, I. (2007). Conversations in leadership. South African perspectives. Randburg: Knowres.

Miller, E.J. (1993). From dependency to autonomy: Studies in organization and change. London: Free Association.

Mollon, P. (2004). Shame and jealousy. The hidden turmoils. London: Karnac

Murphy, A., \& Janeke, H.C. (2009). The relationship between thinking styles and emotional intelligence: An exploratory study. South African Journal of Psychology, 39(3), 357-375

Nel, C. (2009). The new economy requires a value shift. Management Today, 27(5), 8-17.

Neumann, J.E., Kellner, K., \& Dawson-Shepherd, A. (1997). Developing organisational consultancy. London: Routledge.

Newton, J., Long, S., \& Sievers, B. (2006). Coaching in depth. The organisational role analysis approach. London: Karnac.

Nohria, N., \& Khurana, R. (2010). Handbook of leadership theory and practice. Boston: Harvard Business Press.

Northouse, P.G. (2004). Leadership. Theory and practice. Thousand Oaks, SAGE.

Obholzer, A., \& Roberts, V.Z. (1994). The unconscious at work. London: Routledge. http://dx.doi.org/10.4324/9780203359860

Porter-O'Grady, T., \& Malloch, K. (2007). Quantum leadership. A resource for health care innovation. Boston: Jones \& Bartlett. 
Rayner, C., Hoel, H., \& Cooper, C.L. (2002). Workplace bullying. What we know, who is to blame, and what can we do? London: Taylor \& Francis.

Ropo, A., \& Sauer, E. (2008). Dances of leadership: Bridging theory and practice through an aesthetic approach. Journal of Management and Organization, 14(5) 560-572. http://dx.doi.org/10.5172/jmo.837.14.5.560

Schafer, R. (2003). Insight and interpretation. The essential tools of psychoanalysis. London: Karnac.

Shokane, M.S., Stanz, K.J., \& Slabbert, J.A. (2004). Description of leadership in South Africa: Organisational context perspective. South African Journal of Human Resource Management, 2(3), 1-6.

Smit, B., \& Cilliers, F. (2006). Understanding implicit texts in focus groups from systems psychodynamic perspective. The Qualitative Report, 11(2), 302-316.

Straker, D. (2007a). Servant leadership. Retrieved March 08, 2007, from http:// changingminds.org/disciplines/leadership/styles/servant leadership.htm

Straker, D. (2007b). Transformational leadership. Retrieved March 08, 2007, from http://changingminds.org/disciplines/leadership/styles/transformational leadership.htm

Stapley, L.F. (1996). The personality of the organisation. A psycho-dynamic explanation of culture and change. London: Free Association.

Stapley, L.F. (2006a). Global dynamics at the dawn of 2006. Organizational and Social Dynamics, 6(1), 111-142.

Stapley, L.F. (2006b). Individuals, groups and organizations beneath the surface London: Karnac.
Stapley, L.F., \& Collie, A. (2005). Global dynamics at the dawn of 2005. Organizational and Social Dynamics, 5(1), 111-133.

Strümpfer, D.J.W., Eiselen, R.J., Meiring, D., \& Phalatse, J.S. (2010). Validating measures of psychological well-being by contrasting samples employees in hazardous and less hazardous work. Journal of Psychology in Africa, 20(1), 23-32.

Terre Blanche, M., Durrheim, K., \& Painter, D. (2006). Research in practice. Applied methods for the social sciences. Cape Town: UCT Press.

Thompson, G., \& Vecchio, R.P. (2009). Situational leadership theory: A test of three versions. Leadership Quaterly, 20(5), 837. http://dx.doi.org/10.1016/j. leaqua.2009.06.014

Turquet, P.M. (1974). Leadership: The individual and the group. In G.S. Gibbard, J. Harman, \& L. Wells (Eds.), Analysis of groups (pp. 349-371). San Fransisco: JosseyBass.

Van Der Colff, J.J., \& Rothmann, S. (2009). Occupational stress, sense of coherence, coping, burnout and work engagement of registered nurses in South Africa. South African Journal for Industrial Psychology, 35(1), Art. \#423, 10 pages.

Vansina, L.S., \& Vansina-Cobbaert, M. (2008). Psychodynamics for consultants and managers. London: Wiley-Blackwell.

Watts, L. (2009). Managing self in role: Using multiple methodologies to explore self construction and self governance. In S. Clarke \& P. Hoggett (Eds.), Researching beneath the surface. Psycho-social research methods in practice (pp. 215-239). London: Karnac.

Yun, S., Cox, J., \& Sims, J.P. (2006). The forgotten follower: A contingency model of leadership and follower self-leadership. Journal of Managerial Psychology: Self leadership, 21(4), 374-388. 